\title{
VARIABILITY OF VALUES OF PHYSICOCHEMICAL WATER QUALITY INDICES ALONG THE LENGTH OF THE IWONICZANKA STREAM
}

\author{
Andrzej Bogdał', Tomasz Kowalik' \\ 1 Department of Land Reclamation and Environmental Development, University of Agriculture in Krakow, \\ Al. Mickiewicza 24-28, 30-059 Kraków, Poland, e-mail: rmbogdal@cyf-kr.edu.pl; rmkowali@cyf-kr.edu.pl
}

Received: 2015.09 .06 Accepted: 2015.10.06 Published: 2015.11.10

\begin{abstract}
The paper aims at presentation of the effect of changes in the catchment area management on the value of water quality physicochemical indices along the length of the Iwoniczanka stream, which flows through Iwonicz-Zdrój, one of the oldest health resorts in Poland. Analyses of 14 water quality indices were conducted from November 2013 to May 2014 in five measurement points: two situated in the upper course of the stream - in forest areas, two located in the area of Iwonicz-Zdrój town, and one below the rural built-up area. On the basis of the conducted data analysis it was found that the mean values of $\mathrm{pH}$, electrolytic conductivity, sulphates, calcium, total iron and manganese were increasing with the course of flowing water, as evidenced by the water enrichment in substances which had their sources in built-up areas. On average, the highest values of biogenic indices and chlorides but the lowest values of oxygen indices were registered immediately below the location of drain collector from the closed sewage treatment plant, which resulted in pollution of the analysed stream bed with the substances previously drained from the treatment plant. Water flowing through the forest areas had the maximum ecological potential in the built-up areas and due to phosphate concentrations it was classified to class II and then, due to self-purification, returned to the physicochemical parameters appropriate for class I water. The conducted hydro-chemical tests confirmed a significant negative effect of built-up areas on the quality of the flowing waters.
\end{abstract}

Keywords: water quality parameters, ecological potential, anthropogenic pollution.

\section{INTRODUCTION}

Water, which is a natural resource of the natural environment, is prone to pollution at almost each stage of its hydrogeological cycle. It leads to decreasing its quality parameters, and therefore, to reducing the possible utilization of its resources for environmental or economic purposes of people [Roger 1994, Bogdał and Ostrowski 2007, Bulut et al. 2010, Hus and Pulikowski 2011, Kanownik and Rajda 2011].

Water resources are one of the most important environmental components stimulating civilizational and economic development of countries. On the territory of Poland surface water resources are small and irregularly distributed in space and time. For these reasons, while using and shaping such meagre resources, one should remember to proceed in compliance with the principles of sustainable development, which assume bringing together the resources protection with a complex and multifunctional management of rural areas [Rilp and Hildmann 2000, Koc and GlińskaLeszczuk 2004, Sobczyński and Joniak 2013, Kanownik and Rajda 2011].

Deteriorating state of water quality is the driver of increasingly intensive investigations aiming at understanding the processes occurring in the aquatic environment and associated hydrological characteristics. Important pollution sources of surface waters in the rural areas are, among others, municipal sewage, animal husbandry wastes, precipitations and chemicals used in agriculture [Koc and Glińska-Leszczuk 2004, 
Ostrowski et al. 2005, Aydin 2007, Kupiec 2010, Hus and Pulikowski 2011, Kanownik and Rajda 2011, Kowalik et al. 2014, Policht-Latawiec et al. 2014]. Hydrochemistry of rain undergoes constant changes resulting from the location with respect to pollutant emitters, the weather conditions and processes occurring in the atmosphere. On the other hand, changes of physicochemical properties of surface waters, including seasonal changes, are the resultant of the pollutant inflow from anthropogenic sources and natural erosion processes, air and water temperature, plant vegetation, etc. [Hillbricht-Ilkowska 1994, Grosbois et al. 2001, Glińska-Leszczuk 2002, Wiatkowski and Paul 2009, Balcerzak and Rybicki 2011, Kowalik et al. 2014].

The quality of surface waters should be constantly under control, which would allow for possible determining the needs concerning their protection against contamination. It is particularly important in the mountain and highland areas, which determine water management of the lower situated areas of Poland [Szalińska and Dominik 2006, Policht-Latawiec et al. 2014]. For many years point sources of contamination were considered the main cause of deterioration of surface water quality. Over the years, it was noticed that despite its reduction or even elimination, water quality did not improve or got only slightly better. The cause are the pollutants originating from area sources, connected with precipitation and agricultural use of soil. In order to be able to solve the problem of natural environment pollution, it becomes necessary to constantly broaden the knowledge about its functioning, but also about the causes and effects of pollution of the individual environmental components, including waters [Smoroń 1998, Ostrowski et al. 2005, Liberacki and Szafrański 2008, Sojka et al. 2008, Wiatkowski and Paul 2009, Kupiec 2010, Wiatkowski et al. 2012].

The paper aims at presenting the effect of changes in the catchment area management on the value of physicochemical indices of water quality along the length of the Iwoniczanka stream, which flows through Iwonicz-Zdrój, one of the oldest health resorts in Poland.

\section{MATERIAL AND METHODS}

The Iwoniczanka stream, whose water quality is the subject of the present paper, flows from the southern slopes of the Przymiarki mountain range situated by the north-eastern boundaries of Lubatowa village (Podkarpackie voivodship, Poland). It flows through Iwonicz-Zdrój town and through the area of Iwonicz village, flowing into the Lubatówka river at the $11.4 \mathrm{~km}$ of its course. On the bases of the physiographic study conducted by the authors it was established that the length of the Iwonicznka stream is $13.92 \mathrm{~km}$ and its catchment area is $25.36 \mathrm{~km}^{2}$. The Iwonicznaka is strongly changed uniform part of surface waters (JCWP) and regarding abiotic factors it is classified to type 12 flysch streams. The area of the Iwoniczanka catchment is situated in the Outer Western Carpathian province (513), within the range of two macroregions: Small Beskidy Mts. (from the south, 513.71) and Bukowskie Foothills (from the north, 513.69). Both physico-geographical units differ with their relief. In the northern part of the catchment, arable lands and grasslands prevail, occupying totally about $60 \%$ of the area. Forest complexes located mainly in the southern part of the catchment cause that the afforestation of the area is on the level of $23 \%$. A considerable part of the catchment is occupied by a built-up area (Figure 1); its quite large share makes up $13.9 \%$. In the upper course of the Iwoniczanka stream water is taken for water supply systems. Sewage originating from the localities composing Iwonicz-Zdrój district is drained to a collective sewage treatment plant in Krosno.

Physicochemical water quality indices in the Iwoniczanka stream were investigated from November 2013 to May 2014 in the laboratories of Department of Land Reclamation and Environmental Development, University of Agriculture in Krakow. Samples were collected in five measurement points situated along the length of the Iwoniczanka stream (Figure 1). The first was located at $\mathrm{km} 4+670$ of the stream course, below Iwonicz urban built-up area, the second $(\mathrm{km} \mathrm{5+870)}$ between Iwonicz village and Iwonicz-Zdrój town, the third $(\mathrm{km} \mathrm{7+080)}$ in Iwonicz-Zdrój town - 20 $\mathrm{m}$ below the site where a collector from sewage treatment plans used to be situated until 21 February 2012, the fourth $(\mathrm{km} \mathrm{11+540)}$ immediately above Iwonicz-Zdrój built-up area - below the water intake for water treatment plant and the fifth $(\mathrm{km} \mathrm{12+040)}$ in the upper part of the catchment (Figure 1). 14 physicochemical indices from the indices group of acidification $(\mathrm{pH})$, oxygen (oxygen saturation degree, dissolved oxygen), biogenic (phosphates $-\mathrm{PO}_{4}^{-3}$, ammonium nitrogen $-\mathrm{N}-\mathrm{NH}_{4}^{+}$, nitrite nitrogen $\mathrm{N}-\mathrm{NO}_{2}^{-}$, nitrate 


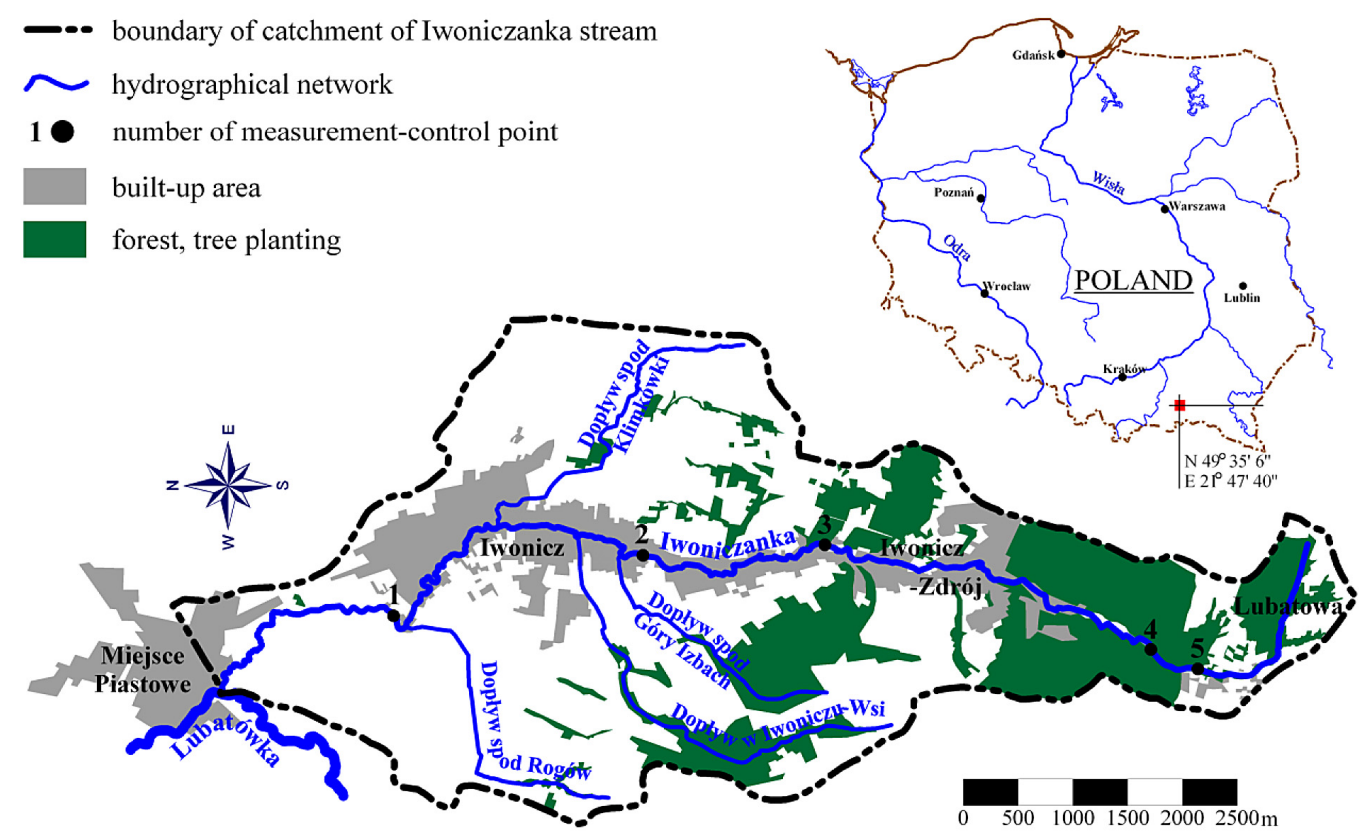

Figure 1. Use and location of the Iwoniczanka stream catchment and location of measurement-control points

nitrogen - $\mathrm{N}-\mathrm{NO}_{3}^{-}$), salinity (electrolytic conductivity, sulphates $\mathrm{SO}_{4}{ }^{2-}$, chlorides $-\mathrm{Cl}^{-}$, calcium $\mathrm{Ca}^{2+}$, magnesium $-\mathrm{Mg}^{2+}$ ) and metals (total iron $-\mathrm{Fe}_{\text {total }}$ and manganese $-\mathrm{Mn}^{2+}$ ) were determined in the water samples using referential methods [Rozporządzenie MŚ 2011].

The minimum and maximum values were determined. Arithmetic mean, standard deviation and variation coefficient were computed for each analysed water quality index. Moreover, the values of the analyzed physicochemical indices were subjected to a detailed statistical analysis, which verified the normality of data distributions by means of Shapiro-Wilk test and the homogeneity of variances in groups using Brown-Forsythe test. Because a number of empirical data groups were compared, out of which no normality of distributions was found for a majority of cases, a non-parametric Kruskal-Wallis test was used for the estimation of the significance of differences between the values of water quality indices tested in different measurement points.

A cluster analysis was conducted on the basis of the obtained physicochemical indices to group the measurement points regarding the similarity of water quality in the Iwoniczanka stream. Estimation of the distances between the clusters was conducted by means of Ward agglomerative method with Euclidean distances, which bases on the analysis of variance and aims at minimizing the sum of squares of any two clusters. The analysis was conducted by means of a licensed computer software STATISTICA 10, in four variants using:

- oxygen indices (dissolved oxygen, oxygen saturation degree),

- biogenic indices (phosphates, ammonium nitrogen, nitrite and nitrate nitrogen),

- salinity indices (electrolytic conductivity, sulphates, chlorides, calcium and magnesium),

- all 14 analysed physicochemical indices.

Since the analysed water quality indices are stated in various units and have very different range of values, the empirical data were standardized in order to make them comparable and avoid the load phenomenon. The cluster analysis yielded the hierarchy of clusters presented as dendrograms.

The assessment of ecological potential of the Iwoniczanka stream water was made in each measurement-control point in compliance with the Regulation of the Minister of the Environment of 23 October, 2013 on the classification of the uniform parts of surface waters and environmental quality standards for priority substances [Rozporządzenie MŚ 2014].

\section{RESULTS}

Mean values of $\mathrm{pH}$, electrolytic conductivity, sulphates, calcium, total iron and manganese (Table 1) were increasing with the course of flowing water in the Iwonicznka stream. The reason for 


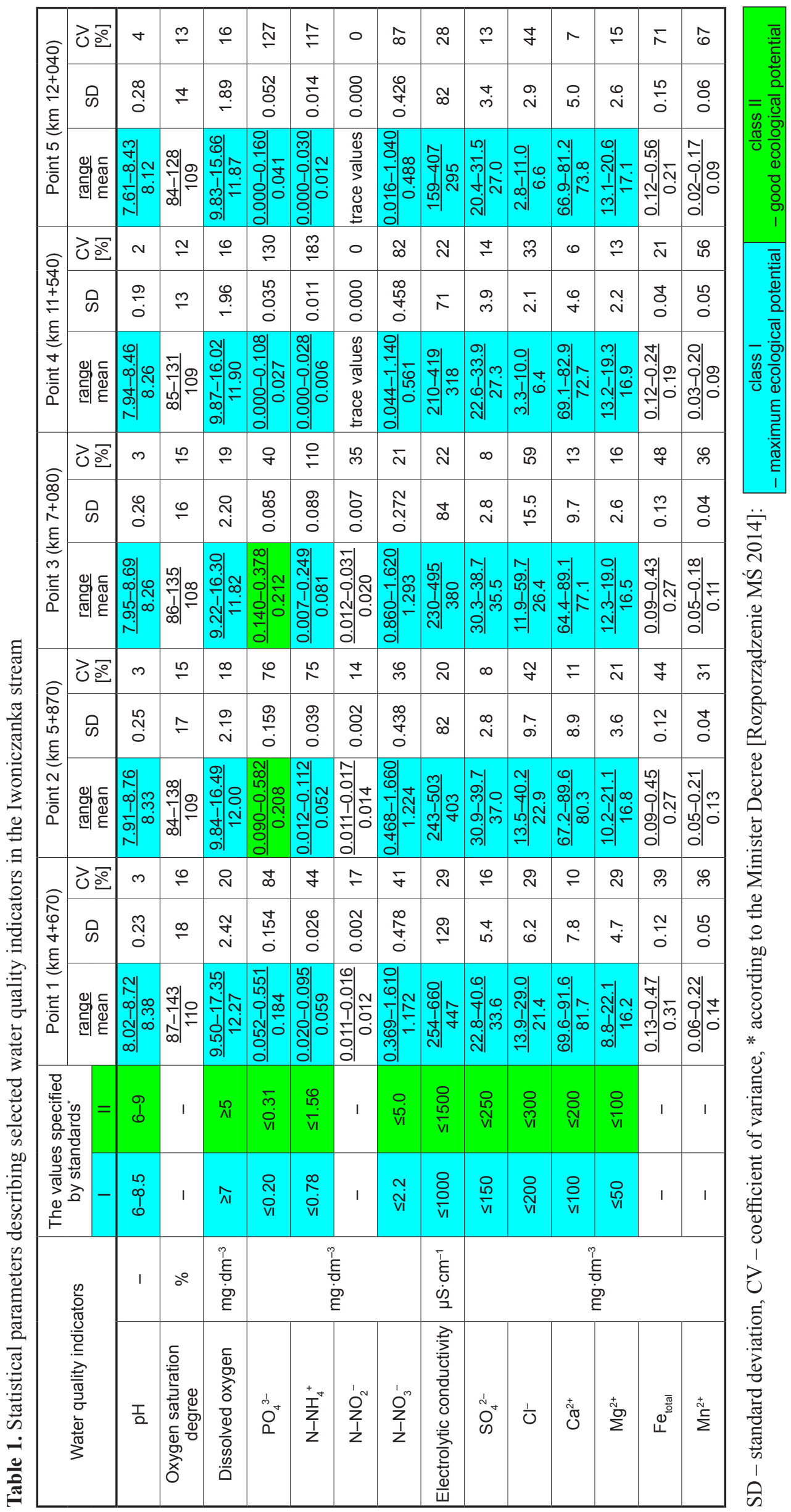


this state of affairs was surface water enrichment in the substances which have their sources in the built-up areas and their runoffs with precipitation waters from the roads and premises. Along the whole analysed reach of the Iwoniczanka, its water contained similar amounts of oxygen, however on average more advantageous oxygen conditions were in points 1 and 2 (Table 1 ), which is connected with a higher flow velocity in the regulated river bed. On average highest values of all analysed biogenic indices and chlorides, but the lowest values of oxygen indices were registered in point 3 (Table 1), situated $20 \mathrm{~m}$ below the place where 9 months earlier drain collector of low efficient sewage treatment plant used to be located. Despite its closure, water quality in this place is still the worst, which may be due to the Iwoniczanka bed pollution with the substances formerly drained from the sewage treatment plant. It may be also supposed that with time, both in this place and below it the water quality will improve. The more so, as even now a decrease in biogens concentrations and improvement of oxygen conditions as a result of water self-purification processes may be observed in points 1 and 2 (Table 1).

On the basis of variation coefficient $(\mathrm{CV})$, which is an objective and comparable measure of empirical data deviation from the mean values, it may be inferred about the random variability of water physicochemical characteristics of water. In case of the investigated waters of the Iwonicznaka stream one may speak about a low variability $(\mathrm{CV} \leq 20 \%)$ of $\mathrm{pH}$ value, oxygen saturation degree, dissolved oxygen, sulphates and calcium. The greatest dynamics of changes, with some exceptions, was observed for phosphate concentrations and ammonium nitrogen $\mathrm{CV} \geq 60 \%$ (Table 1 ).

Table 2. Comparison of water quality indicators values using non-parametrical Kruskala-Wallisa test

\begin{tabular}{|c|c|c|c|c|c|c|c|c|c|c|c|c|c|c|c|c|c|}
\hline \multicolumn{6}{|c|}{$\mathrm{pH}[-]$} & \multicolumn{6}{|c|}{ Oxygen saturation degree [\%] } & \multicolumn{6}{|c|}{ Dissolved oxygen $\left[\mathrm{mg} \mathrm{O}_{2} \cdot \mathrm{dm}^{-3}\right]$} \\
\hline \multirow[t]{2}{*}{ Pkt } & & 1 & 2 & 3 & 4 & \multirow[t]{2}{*}{ Pkt } & & 1 & 2 & 3 & 4 & \multirow[t]{2}{*}{ Pkt } & & 1 & 2 & 3 & 4 \\
\hline & $\mathrm{Me}$ & 8.44 & 8.34 & 8.26 & 8.30 & & $\mathrm{Me}$ & 111 & 109 & 110 & 111 & & $\mathrm{Me}$ & 11.87 & 11.53 & 11.36 & 11.48 \\
\hline 2 & 8.34 & 1.00 & & & & 2 & 109 & 1.00 & & & & 2 & 11.53 & 1.00 & & & \\
\hline 3 & 8.26 & 1.00 & 1.00 & & & 3 & 110 & 1.00 & 1.00 & & & 3 & 11.36 & 1.00 & 1.00 & & \\
\hline 4 & 8.30 & 1.00 & 1.00 & 1.00 & & 4 & 111 & 1.00 & 1.00 & 1.00 & & 4 & 11.48 & 1.00 & 1.00 & 1.00 & \\
\hline 5 & 8.13 & 0.42 & 1.00 & 1.00 & 1.00 & 5 & 108 & 1.00 & 1.00 & 1.00 & 1.00 & 5 & 11.55 & 1.00 & 1.00 & 1.00 & 1.00 \\
\hline \multicolumn{6}{|c|}{$\mathrm{PO}_{4}^{3-}\left[\mathrm{mg} \cdot \mathrm{dm}^{-3}\right]$} & \multicolumn{6}{|c|}{$\mathrm{N}-\mathrm{NH}_{4}^{+}\left[\mathrm{mg} \cdot \mathrm{dm}^{-3}\right]$} & \multicolumn{6}{|c|}{$\mathrm{N}-\mathrm{NO}_{2}^{-}\left[\mathrm{mg} \cdot \mathrm{dm}^{-3}\right]$} \\
\hline \multirow[t]{2}{*}{ Pkt } & & 1 & 2 & 3 & 4 & \multirow[t]{2}{*}{ Pkt } & & 1 & 2 & 3 & 4 & \multirow[t]{2}{*}{ Pkt } & & 1 & 2 & 3 & 4 \\
\hline & $\mathrm{Me}$ & 0.145 & 0.160 & 0.170 & 0.015 & & $\mathrm{Me}$ & 0.055 & 0.050 & 0.040 & 0.000 & & $\mathrm{Me}$ & 0.012 & 0.014 & 0.018 & 0.000 \\
\hline 2 & 0.160 & 1.00 & & & & 2 & 0.050 & 1.00 & & & & 2 & 0.014 & 1.00 & & & \\
\hline 3 & 0.170 & 1.00 & 1.00 & & & 3 & 0.040 & 1.00 & 1.00 & & & 3 & 0.018 & 0.95 & 1.00 & & \\
\hline 4 & 0.015 & 0.03 & 0.01 & 0.00 & & 4 & 0.000 & 0.01 & 0.04 & 0.03 & & 4 & 0.000 & 0.05 & 0.01 & 0.00 & \\
\hline 5 & 0.025 & 0.04 & 0.04 & 0.01 & 1.00 & 5 & 0.007 & 0.04 & 0.04 & 0.05 & 1.00 & 5 & 0.000 & 0.05 & 0.01 & 0.00 & 1.00 \\
\hline \multicolumn{6}{|c|}{$\mathrm{N}-\mathrm{NO}_{3}^{-}\left[\mathrm{mg} \cdot \mathrm{dm}^{-3}\right]$} & \multicolumn{6}{|c|}{ Electrolytic conductivity $\left[\mu \mathrm{S} \cdot \mathrm{cm}^{-1}\right]$} & \multicolumn{6}{|c|}{$\mathrm{SO}_{4}^{2-}\left[\mathrm{mg} \cdot \mathrm{dm}^{-3}\right]$} \\
\hline \multirow[t]{2}{*}{ Pkt } & & 1 & 2 & 3 & 4 & \multirow[t]{2}{*}{ Pkt } & & 1 & 2 & 3 & 4 & \multirow[t]{2}{*}{ Pkt } & & 1 & 2 & 3 & 4 \\
\hline & $\mathrm{Me}$ & 1.434 & 1.444 & 1.296 & 0.338 & & $\mathrm{Me}$ & 454 & 392 & 389 & 307 & & $\mathrm{Me}$ & 33.6 & 37.6 & 36.1 & 26.3 \\
\hline 2 & 1.444 & 1.00 & & & & 2 & 392 & 1.00 & & & & 2 & 37.6 & 1.00 & & & \\
\hline 3 & 1.296 & 1.00 & 1.00 & & & 3 & 389 & 1.00 & 1.00 & & & 3 & 36.1 & 1.00 & 1.00 & & \\
\hline 4 & 0.338 & 0.03 & 0.04 & 0.03 & & 4 & 307 & 0.04 & 0,92 & 1.00 & & 4 & 26.3 & 0.04 & 0.00 & 0.03 & \\
\hline 5 & 0.350 & 0.04 & 0.04 & 0.02 & 1.00 & 5 & 297 & 0.03 & 0.34 & 0.83 & 1.00 & 5 & 27.4 & 0.04 & 0.00 & 0.03 & 1.00 \\
\hline \multicolumn{6}{|c|}{$\mathrm{Cl}^{-}\left[\mathrm{mg} \cdot \mathrm{dm}^{-3}\right]$} & \multicolumn{6}{|c|}{$\mathrm{Ca}^{2+}\left[\mathrm{mg} \cdot \mathrm{dm}^{-3}\right]$} & \multicolumn{6}{|c|}{$\mathrm{Mg}^{2+}\left[\mathrm{mg} \cdot \mathrm{dm}^{-3}\right]$} \\
\hline \multirow[t]{2}{*}{ Pkt } & & 1 & 2 & 3 & 4 & \multirow[t]{2}{*}{ Pkt } & & 1 & 2 & 3 & 4 & Pkt & & 1 & 2 & 3 & 4 \\
\hline & $\mathrm{Me}$ & 20.5 & 19.5 & 21.8 & 6.2 & & $\mathrm{Me}$ & 80.4 & 80.9 & 75.9 & 70.6 & & $\mathrm{Me}$ & 16.6 & 16.6 & 17.2 & 17.2 \\
\hline 2 & 19.5 & 1.00 & & & & 2 & 80.9 & 1.00 & & & & 2 & 16.6 & 1.00 & & & \\
\hline 3 & 21.8 & 1.00 & 1.00 & & & 3 & 75.9 & 1.00 & 1.00 & & & 3 & 17.2 & 1.00 & 1.00 & & \\
\hline 4 & 6.2 & 0.01 & 0.01 & 0.00 & & 4 & 70.6 & 0.29 & 0.76 & 1.00 & & 4 & 17.2 & 1.00 & 1.00 & 1.00 & \\
\hline 5 & 6.7 & 0.01 & 0.01 & 0.00 & 1.00 & 5 & 73.6 & 0.61 & 1.00 & 1.00 & 1.00 & 5 & 17.4 & 1.00 & 1.00 & 1.00 & 1.00 \\
\hline & & $\mathrm{e}_{\text {Total }}[\mathrm{n}$ & $\mathrm{gg} \cdot \mathrm{dm}^{-}$ & & & & & $\mathrm{Mn}^{2+}[\mathrm{m}$ & $\mathrm{g} \cdot \mathrm{dm}^{-3}$ & & & & Wat & ter quali & ity indic & sator & \\
\hline Pkt & & 1 & 2 & 3 & 4 & Pkt & & 1 & 2 & 3 & 4 & Pkt & & 1 & 2 & 3 & 4 \\
\hline & $\mathrm{Me}$ & 0.36 & 0.22 & 0.23 & 0.19 & & $\mathrm{Me}$ & 0.15 & 0.13 & 0.11 & 0.10 & & $\mathrm{Me}$ & $\mathrm{Me}$ & $\mathrm{Me}$ & $\mathrm{Me}$ & $\mathrm{Me}$ \\
\hline 2 & 0.22 & 1.00 & & & & 2 & 0.13 & 1.00 & & & & 2 & $\mathrm{Me}$ & $p$ & & & \\
\hline 3 & 0.23 & 1.00 & 1.00 & & & 3 & 0.11 & 1.00 & 1.00 & & & 3 & $\mathrm{Me}$ & $p$ & $\mathrm{p}$ & & \\
\hline 4 & 0.19 & 1.00 & 1.00 & 1.00 & & 4 & 0.10 & 0.72 & 1.00 & 1.00 & & 4 & $\mathrm{Me}$ & $p$ & $p$ & $\mathrm{p}$ & \\
\hline 5 & 0.15 & 0.40 & 1.00 & 1.00 & 1.00 & 5 & 0.10 & 0.76 & 1.00 & 1.00 & 1.00 & 5 & $\mathrm{Me}$ & $p$ & $p$ & $p$ & $\mathrm{p}$ \\
\hline
\end{tabular}

$\mathrm{Me}-$ median, $\mathrm{p}$ - probability test, * bold type indicates significant differences (for $\alpha=0.05$ ). 
On the basis of the average values of 10 investigated physicochemical indices and values permissible for individual quality classes [Rozporządzenie MŚ 2014] it was established that water in points 1,4 and 5 had a maximum ecological potential. On the other hand, due to raised phosphate concentrations in points 2 and 3 , the water was classified to class II - good ecological potential (Table 1).

Analysis of the empirical data conducted using Kruskal-Wallis test on the significance level $\alpha=0.05$ revealed, that there are no statistically significant differences between the values of all tested water quality indices in points 1, 2 and 3. The differences between the values of indices noted in points 4 and 5 also proved statistically insignificant (Table 2).

However, clear and statistically higher values were registered between the groups of points (1, 2 and 3-4 and 5) for the following indices: phosphates, ammonium nitrogen, nitrite nitrogen, ni- trate nitrogen, sulphates and chlorides. Moreover, a higher electrolytic conductivity was measured in point 1 than in two points situated in the upper course of the Iwoniczanka, i.e. in points 4 and 5 (Table 2). The results of statistical test confirm the major impact of the area management on water quality, in this case settlements or forest.

Four dendrograms (Figure 2), showing the similarity of water quality in the individual measurement points, were obtained in result of the cluster analysis conducted using Ward method separately for oxygen, biogenic and salinity indices, and jointly for all 14 analysed physicochemical indices. For the oxygen indices, three clusters were obtained at the bond distance on level 2 (Figure 2a): the first comprising only point 1 , in which the most advantageous oxygen conditions were noted in the water, the second comprising point 2 and points 4 and 5 in which a medium water saturation with oxygen was noted and the third cluster composed of point 3 , where
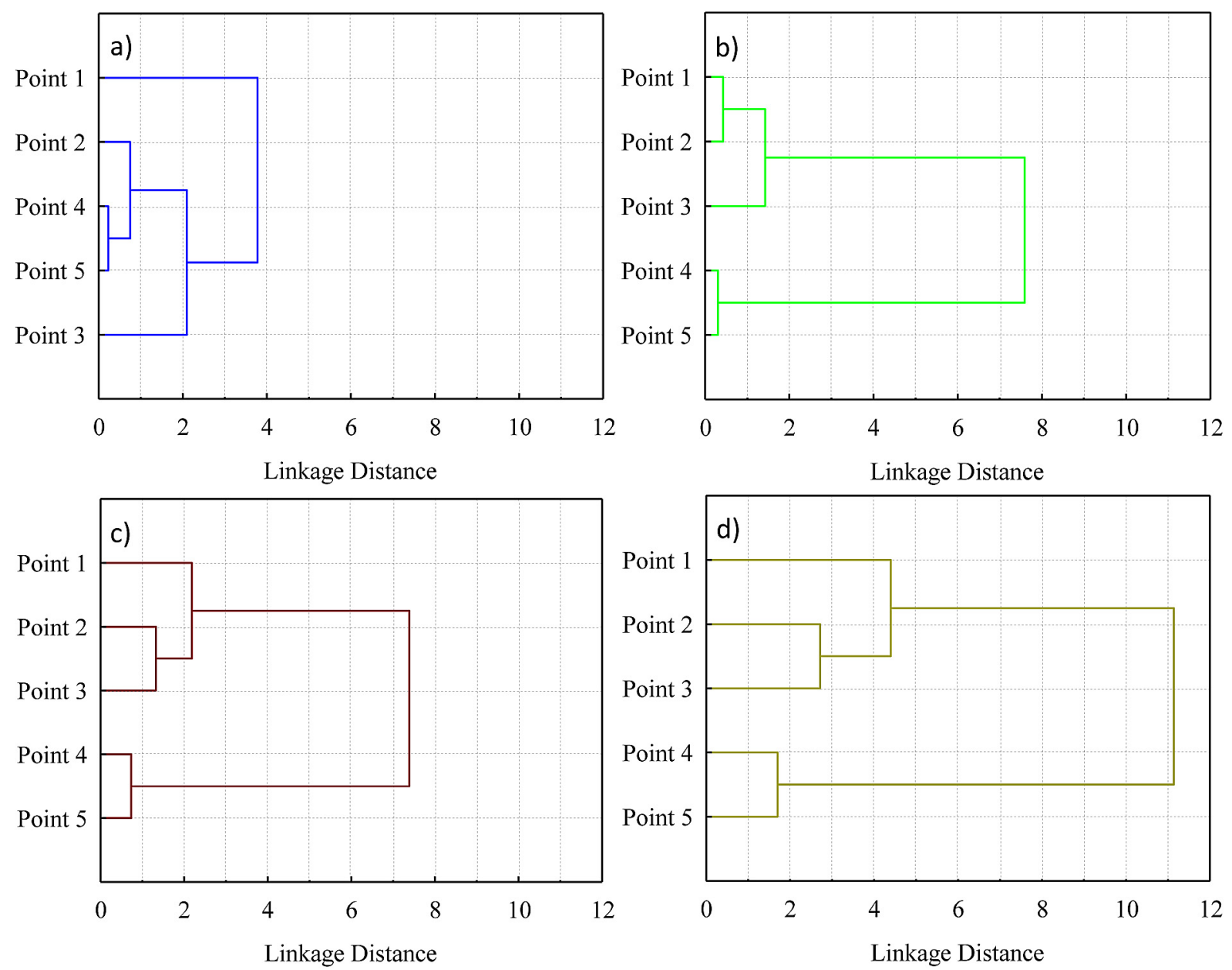

Figure 2. The dendrograms (Ward's metod - Euklidean Distance) showing similarity of surface water quality examined in individual measurement-control points, taking into account the values of: a) oxygen indicators,

b) nutrient indicators, c) salinity indicators, d) all examined physicochemical indicators 
water containing the least of dissolved oxygen and the least saturated with oxygen was observed. Due to biogenic indices, also at the bond distance on level 2, two clusters formed (Figure $2 \mathrm{~b}$ ): the first comprising points 1,2 and 3 with quite high biogen concentrations and the second made up of points 4 and 5, in which water contained much lower amounts of biogenic substances. Water salinity was very similar (Figure 2c) in two pairs of measurement-control points -2 and 3, and in 4 and 5, however, the values of salinity indices were much lower in the second pair of points. Slightly different water salinity occurred in point 1 , but it was similar to observed in points 2 and 3 . Considering all the tested indices, the similarity of water quality between points was less noticeable than in the previous variants, because only at the bond distance on the level 5, two clusters formed (Figure 2d): the first comprising points 1,2 and 3 situated in the urban and rural built-up areas, where water had less favourable physicochemical parameters than in points 4 and 5 , which were situated in the upper course of the Iwoniczanka river, in forest areas (cluster two).

\section{CONCLUSIONS}

The following conclusions can be drawn from the analysis of data obtained over several months of hydrochemical testing of water flowing into the Iwoniczanka stream:

1. Mean values of $\mathrm{pH}$, electrolytic conductivity, sulphates, calcium, total iron and manganese were increasing with the course of flowing water, which was caused by the water enrichment in the substances originating from the built-up areas.

2. On average highest values of biogenic indices and chlorides but the lowest values of oxygen indices were registered immediately below the location of the drain collector of the closed sewage treatment plant, which resulted in the investigated stream bed pollution with the substances formerly drained from the treatment plant.

3. Water flowing through the forest areas had the maximum ecological potential, in the compact urban development areas it was classified to class II because of phosphate concentrations and further, as a result of self-purification it returned to the physicochemical parameters appropriate for water in class I.

4. The analysis of the collected data revealed a significant impact of built-up areas on the quality of flowing waters.

\section{REFERENCES}

1. Aydin A. 2007. The microbiological and physicochemical quality of groundwater in West Thrace, Turkey. Polish J. Environ. Stud., 16, 3, 377-383.

2. Balcerzak W.P., Rybicki S.M. 2011. Ocena stopnia zagrożenia wody eutrofizacją na przykładzie zbiornika zaporowego w Świnnej Porębie. Ochrona Środowiska, 33, 4, 67-69.

3. Bogdał A. Ostrowski K. 2007. Wpływ rolniczego użytkowania zlewni podgórskiej i opadów atmosferycznych na jakość wód odpływających z jej obszaru. Woda-Środowisko-Obszary Wiejskie, 7, 2a (20), 59-69.

4. Bulut N.V., Bayram A., Gundogdu A., Soylak M., Tufekci M. 2010. Assessment of water quality parameters in the stream Galyan, Trabzon, Turkey. Environmental Monitoring and Assessment, 165, $1-13$.

5. Glińska-Lewczuk K. 2002. Influence of an agricultural catchment on the functioning of riverlake system. Zesz. Probl. Post. Nauk Roln., 484, 163-173.

6. Grosbois C., Negrel P. Grimaud D., Fouillac C. 2001. An Overview of Dissolved and Suspended Matter Fluxes in the Loire River Basin: Natural and Anthropogenic Inputs. Aquatic Geochemistry, 7, 81-105.

7. Hillbricht-Ilkowska A. 1994. Characteristic of water supplied by rivers and its influence on lake water in Suwalski Landscape Park. In: Hillbricht-Ilkowska A., Wiśniewki R.J., (Ed.) Jeziora Suwalskiego Parku Krajobrazowego. Związki z krajobrazem, stan eutrofizacji i kierunki ochrony. Kom. Nauk. PAN „Człowiek i Środowisko”, 7, 163-170.

8. Hus T., Pulikowski K. 2011. Content of nitrogen compounds in water flowing out of small agricultural catchments. Pol. J. Environ. Stud., 20, 4, 895-902.

9. Kanownik W., Rajda W. 2011. Samooczyszczanie wody potoku Pychowickiego. Zesz. Prob. Post. Nauk Rol., 561, 81-91.

10. Koc J., Glińska-Lewczuk K. 2004. Hydrochemical characteristics of spring water in young glacial area on the example of the Łyna River headwater. Journal of Elementology, 9 (1), 25-34.

11. Kowalik T., Kanownik W., Bogdał A., Policht-Latawiec A. 2014. Wpływ zmian użytkowania zlewni 
wyżynnej na kształtowanie jakości wody powierzchniowej. Rocznik Ochrona Środowiska (Annual Set The Environment Protection), 16, 223-238.

12. Kupiec J. 2010. Porównanie wyników bilansu fosforu $\mathrm{w}$ aspekcie monitorowania zanieczyszczeń ze źródeł rolniczych. Rocznik Ochrona Środowiska (Annual Set The Environment Protection), 12, 785-804.

13. Liberacki D., Szafrański Cz. 2008. Contents of biogenic components in surface waters of small catchments in the Zielonka Forest. Rocznik Ochrona Środowiska (Annual Set The Environment Protection), 10, 181-192.

14. Ostrowski K., Bogdał A., Rajda W. 2005. Wpływ użytkowania wybranych mikrozlewni Pogórza Wielickiego na zawartość i sezonową zmienność cech fizyko-chemicznych w wodach odpływających. Zesz. Nauk. AR Kraków, 420, ser. Inż. Środ., 26, 9-19.

15. Policht-Latawiec A., Bogdał A., Kanownik W., Kowalik T., Ostrowski K., Gryboś P. 2014. Jakość i walory użytkowe wody małej rzeki fliszowej. Rocznik Ochrona Środowiska (Annual Set The Environment Protection), 16, 546-561.

16. Ripl W, Hildmann CH. 2000. Dissolved load transported by rivers as an indicator of landscape sustainability. Ecological Engineering, 14, 373-387.

17. Rogers P. 1994. Hydrology and Water Quality. Changes in Land Use and Land Cover: A global perspective, Cambridge University Press. Cambridge.

18. Rozporządzenie Ministra Środowiska z dnia 15 listopada 2011 r. W sprawie form i sposobu pro- wadzenia monitoringu jednolitych części wód powierzchniowych i podziemnych. Dz. U. Nr 258, poz. 1550 .

19. Rozporządzenie Ministra Środowiska z dnia 22 października 2014 roku w sprawie sposobu klasyfikacji stanu jednolitych części wód powierzchniowych oraz środowiskowych norm jakości dla substancji priorytetowych. Dz. U. z 2014 r., poz. 1482.

20. Sojka M., Siepak M., Zioła A., Frankowski M., Murat-Błażejewska S., Siepak J. 2008. Application of multivariate statistical techniques to evaluation of water quality in the Mała Wełna River (Western Poland). Environ. Monit. Assess., 147, 159-170.

21. Smoroń S. 1998. Eutrophication of surface water as an influence of biogenic compounds penetration from the agriculture sources to the Environmental. Zesz. Eduk. IMUZ, 5, 57-70.

22. Sobczyński T., Joniak T. 2013. The Variability and Stability if Water Chemistry in a Deep Temperate Lake: Results of Long-Term Study of Eutrophication. Pol. J. Environ. Stud., 22, 1, 227-237.

23. Szalińska E., Dominik J. 2006. Water quality changes in the upper Dunajec Watershed, Southern Poland. Polish J. Environ. Stud., 15, 2, 327-334.

24. Wiatkowski M., Paul L. 2009. Surface water quality assessment in Troja river catchment in the context of Włodzienin reservoir construction. Polish J. Environ. Stud., 18, 5, 923-929.

25. Wiatkowski M., Rosik-Dulewska Cz., Gruss Ł. 2012. Profile of water quality indicatores changes in Stobrawa river. Infrastructure and Ekology of Rural Areas, 3/IV, 21-35. 